МОДЕЛЬ ПРОФЕСІЙНОЇ ПІДГОТОВКИ МАЙБУТНІХ СОЦІАЛЬНИХ ПЕДАГОГІВ ДО ФОРМУВАННЯ ЖИТТЄВОЇ КОМПЕТЕНТНОСТІ ПІДЛІТКІВ У ЗАКЛАДАХ ЗАГАЛЬНОЇ СЕРЕДНЬОЇ ОСВІТИ

\title{
MODEL OF PROFESSIONAL PREPARATION OF THE FUTURE SOCIAL PEDAGOGES' IN THE FORMING OF LIFE COMPETENCE OF TEENAGERS IN A GENERAL SCHOOLS
}

УДК 378.046-057.87:373.5.013.42: 005.336.2-053.6(045)

DOI https://doi.org/10.32843/2663-60852019-15-2-4

\section{Великжаніна Д.В.,}

аспірант кафедри педагогіки

і педагогічної майстерності

Мелітопольського державного

педагогічного університету

імені Богдана Хмельницького
У статті розкривається актуальність реалізації компетентнісних оріентирів сучасної системи освіти й набуття молодим поколінням ключових компетентностей для успішної життєдіяльності, самореалізації та соціалізації. У зв'язку з цим виникає необхідність моделювання професійної підготовки майбутніх соціальних педагогів до формування життєвої компетентності підлітків в умовах закладу загальної середньої освіти. Проаналізовано сутність понять «модель», «моделювання», «контент», «навчальнометодичний контентм.. Запропоновано та теоретично обгрунтовано модель професійної підготовки майбутніх соціальних педагогів до формування життєвої компетентності підлітків у закладах загально середньої освіти. Наголошено на цілісності моделі та логічності у взаємозв'язку їі елементів, на можливості їі комплексного та фррагментарного використання, на динамічності й гнучкості моделі, ії придатності до модиррікацій, трансформацій та доповнень. Визначено та охарактеризовано структуру запропонованої моделі, яка складається з цільового, концептуально-методологічного, змістовно-прочесуального та результативного блоків. Окреслено структурні елементи визначених блоків запропонованої моделі: цільовий містить мету та завдання просресійної підготовки майбутніх соціальних педагогів у напрямі фоормування життєвої компетентності підлітків у школі; концептуально-методологічний включає стандарт вищої освіти за спеціальністю 231 «Соціальна робота для першого (бакалаврського) рівня», концептуальні засади, наукові підходи та принципи фрахової підготовки майбутніх фрахівців соціальної сфрери у зазначеному напрямі; змістовно-процесуальний презентує компоненти, педагогічн умови та етапи їх реалізації, навчальнометодичний контент професійної підготовки майбутніх соціальних педагогів до роботи з підлітками у школі в напрямі формування у них життєвої компетентності; результативний містить критерії та рівні, очікувані результати фрахової підготовки майбутніх соціальних педагогів до роботи з підлітками в школі щодо срормування у них ключових компетентностей для успішного життя.

Ключові слова: модель, моделювання, модель профресійної підготовки майбутніх соціальних педагогів до формування життєвої компетентності підлітків у закладах загальної середньої освіти, навчальнометодичний контент, фрахова підготовка майбутніх соціальних педагогів, компетентнісний підхід в освіті, життєва компетентність, підліток.

The article deals with the relevance of the implementation of the competencies of the modern education system and the acquisition of key competences for the younger generation for successful life, self-realization and socialization. In this regard, it is necessary to model the vocational training of future social educators for the formation of adolescents' life competencies in a general secondary education setting. The essence of the concepts "model", "modeling", "content", "educational and methodical content" is analyzed. A model of professional training of future social educators for the formation of adolescents' life competence in general secondary education institutions is proposed and theoretically substantiated. Emphasis is placed on the integrity of the model and the logic in the interrelation of its elements, on the possibility of its complex and fragmentary use, on the dynamic and flexibility of the model, its applicability to modifications, transformations and additions. The structure of the proposed model, which consists of target, conceptual, methodological, substantive, process and resultant blocks, is defined and characterized. The structural elements of the identified blocks of the proposed model are outlined: target - contains the purpose and tasks of professional training of future social educators in the direction of formation of life competence of adolescents in school; conceptual and methodological - includes the standard of higher education in the specialty 231 "Social work for the first (bachelor) level", conceptual foundations, scientific approaches and principles of professional training of future specialists in the social sphere in the specified direction; substantive-procedural - presents the components, pedagogical conditions and stages of their implementation, educational and methodological content of future social pedagogues' professional preparation for work with teenagers in school in the direction of formation of vital competence in them; effective contains criteria and levels, expected results of professional training of future social educators to work with teenagers in school to form key competencies for successful life in them.

Key words: model, modeling, model of professional preparation of future social pedagogues for formation of life competence of adolescents in institutions of general secondary education, educational-methodical content, professional training of future social teachers, competence approach in education, life competence, teenager.
Постановка проблеми у загальному вигляді. Сьогодення вимагає від сучасної особистості динамічності, гнучкості знань та умінь, критичного й творчого мислення, здатності практичного використання теоретичного знання, а також соціальної активності, конкурентоспроможності, самостійності у вирішенні життєвих задач, життєвої компетентності загалом. Тому пріоритетним завданням сучасної освіти в Україні нині $€$ реалізація компетентнісного підходу, який передбачає наближення 
змісту освіти до практики та фрормування в учнів ключових компетентностей для життя. Згідно 3 Концепцією «Нова українська школа», ключов компетентності для життя - це ті компетентності, яких кожен потребує для особистої реалізації, розвитку, активної громадянської позиції, соціальної інклюзії та працевлаштування, які здатні забезпечити особисту реалізацію та життєвий успіх протягом усього життя [8]. Життєва компетентність особистості, своєю чергою, є основою для її успішної самореалізації і передбачає здатність людини вирішувати життєві проблеми самостійно, використовувати накопичений досвід у різних життєвих обставинах. Вітчизняні вчені І. Єрмаков, Л. Несен, Л. Сохань визначають життєву компетентність як: «знання, вміння, життєвий досвід особистості, ії життєтворчі здатності, необхідні для розв'язання життєвих завдань і продуктивного здійснення життя як індивідуального життєвого проєкту, які передбачають свідоме і відповідальне ставлення до виконання особистістю її життєвих і соціальних ролей» [4, с. 9].

Реалізація компетентнісного підходу в освіті, зокрема фрормування життєвої компетентності молодого покоління, значною мірою є об'єктом соціально-педагогічної діяльності, адже сучасний соціальний педагог паралельно та через реалізацію своїх професійних фрункцій у школі покликаний створювати комфрортні та сприятливі умови для соціалізації та соціальної адаптації учнів, розвитку їхньої комунікативності, здатностей визначати життєві цілі, планувати свою життєдіяльність, для формування умінь попереджати та вирішувати консрліктні ситуації.

Специфрічною категорією учнів, з якою працює соціальний педагог у школі, $є$ підлітки. Ця категорія учнів, з огляду на особливості свого психофрізичного та соціального розвитку, характеризується прагненням до самостійності, незалежності, бажанням бути на рівні 3 дорослими, водночас підлітки часто сором'язливі, не впевнені у своїх силах, шукають соціального визнання й ідентифрікації. Соціальний педагог у школі допомагає підліткам не розгубитись на шляху свого особистісного становлення, вибору життєвих цілей та засобів їх досягнення, він здійснює соціально-педагогічний супровід соціального розвитку підлітків, залучає учнів до суспільно корисної діяльності, сприяє розвитку їхнього творчого потенціалу та самореалізації, фрормуванню життєво важливих здатностей на засадах індивідуального підходу, толерантності, поваги до дитини, порядності й чесності, що має особливе значення у налагодженні співпраці 3 учнями підліткового віку.

Формування життєвої компетентності особистості підлітків - процес багатогранний і безперервний. Він вимагає від соціальних педагогів відповідальності й професійної компетентності. Тому актуалізації набуває профресійна підготовка майбутніх соціальних педагогів до формування життєвої компетентності підлітків в умовах закладів загальної середньої освіти. У зв'язку з цим можна констатувати необхідність розробки моделі професійної підготовки майбутніх соціальних педагогів до фрормування життєвої компетентності підлітків у школі.

Аналіз останніх досліджень і публікацій. Нині у професійній підготовці фрахівців широко використовується моделювання як метод наукового пошуку та навчання. Створенню моделей фрахової підготовки соціальних педагогів до роботи в різних напрямах професійної діяльності присвячені наукові дослідження таких вітчизняних учених, як: л. Боднар (модель фрормування підготовленості соціальних педагогів до професійної діяльності із застосуванням електронних засобів навчання), Р. Вайнола (модель забезпечення особистісного розвитку майбутнього соціального педагога в процесі професійної підготовки), О. Карпенко (модель діяльності та модель особистості соціального працівника), Т. Ковальчук (модель формування готовності соціальних педагогів до роботи у сфері дозвілля), І. Ковчина (модель підготовки майбутніх соціальних педагогів до соціально-правової діяльності), О. Лісовець (модель професійної діяльності соціального педагога 3 громадськими дитячими та молодіжними організаціями як науково-теоретичне забезпечення процесу формування готовності майбутніх соціальних педагогів до роботи з громадськими дитячими та молодіжними організаціями), О. Міхєєва (модель професійної підготовки педагогів), Ю. Рябова (модель підготовки майбутніх соціальних педагогів до професійної діяльності в багатонаціональному середовищі), В. Тесленко (модель цільової підготовки фрахівців до реалізації регіональної програми соціально-педагогічної підтримки дітей з обмеженими можливостями), О. Тютюнник (модель та організаційно-педагогічні умови підготовки майбутніх соціальних педагогів до профілактики наркотичної залежності серед старшокласників), 3. Фалинська (модель неперервної практичної підготовки майбутніх соціальних педагогів) та ін. Однак, попри наявний науковий досвід моделювання процесу фахової підготовки соціальних педагогів до професійної діяльності, не досить вивченим, на нашу думку, залишається питання розробки дидактичної моделі професійної підготовки майбутніх соціальних педагогів за таким актуальним напрямом соціально-педагогічної діяльності, як формування життєвої компетентності підлітків у закладах загальної середньої освіти.

Виділення не вирішених раніше частин загальної проблеми. Професійна підготовка майбутніх соціальних педагогів нині орієнтується на потреби й проблеми суспільства, освіти й дитячого 
середовища, які розкриваються у необхідності формування життєвої компетентності молодого покоління. Вона має бути максимально практико зорієнтованою, сучасною, дієвою. Тому важливими аспектами у професійній підготовці майбутніх соціальних педагогів до фрормування життєвої компетентності підлітків $€$ їі комплексність, технологічність й ефективність. Забезпечити реалізацію вищевказаних аспектів фрахової підготовки майбутніх соціальних педагогів у зазначеному напрямі можливо за умов її моделювання, яке консолідує оптимальні складники, ключові ідеї, сутність, методи, фрорми, засоби й технології, кінцеві результати такої підготовки у схемі або структурно-фрункціональній моделі. Тому доцільною $є$ розробка детальної моделі профресійної підготовки майбутніх педагогів до фрормування життєвої компетентності підлітків в умовах школи.

Мета статті. Метою статті $€$ обґрунтування моделі професійної підготовки майбутніх соціальних педагогів до формування життєвої компетентності підлітків у закладах загальної середньої освіти.

Виклад основного матеріалу. Моделювання як метод дослідження передбачає вивчення об'єкта, процесу або явища за допомогою створення його моделі, а також включає три системоутворюючі елементи: суб'єкт дослідження; об'єкт дослідження; модель, яка опосередковує відносини між об'єктом, що вивчається, та суб'єктом, що пізнає [12].

Модель як продукт моделювання визначається як специфічний об'єкт, створений з метою отримання та зберігання інорормації у фрормі уявного образу, опису знаковими засобами (формулами, графріками, схемами та ін.) або матеріального предмета, що відображає властивості, характеристики та зв'язки об'єкта оригінала довільної природи, які є істотними для вирішення суб'єктом певного завдання [2, с. 186].

Модель (від лат. modulus - «міра, аналог, зразок, взірець») - це узагальнений синтезований образ об'єкта-прототипу (явища, процесу), що використовується для вивчення, дослідження, систематизації тощо. Вивчення моделі відображає фрундаментальні властивості об'єкта-прототипу, допомагає виявити ключові ознаки аналізованих процесів, проаналізувати їх динаміку, виявити причинно-наслідкові зв'язки. Модель обов'язково містить прогностичний аспект, пов'язує інформаційний образ теперішнього з теоретичним образом майбутнього [11, с. 238].

Модель також розуміється як предметна, знакова чи уявна система, що відтворює, імітує або відображає якісь визначальні характеристики, тобто принципи внутрішньої організації або фрункціонування, певні властивості чи ознаки об'єкта пізнання (оригіналу), пряме безпосереднє вивчення якого з якихось причин неможливе, неефективне або недоцільне, і може замінити цей об'єкт у процесі, що досліджується, з метою отримання знань про нього [13, с. 391].

Класичним тлумаченням поняття «модель» $€$ визначення В. Штофрфа: «модель» - це подумки уявлена або матеріально реалізована система, яка, відбиваючи або відтворюючи об'єкт дослідження, здатна його замінити таким чином, що вивчення цієї системи надає нову інорормацію про цей об'єкт [14]. І. Зязюн трактує поняття «модель» як: штучно створений зразок у вигляді схеми, конструкцій, знакових фрорм чи фрормул, подібний до досліджуваного об'єкта чи явища, що відображає і відтворює в простому вигляді структуру, властивості й взаємозв'язки та відношення між його елементами [6, с 4-7]. На думку С. Гончаренка, кожна модель має фріксувати найголовніші риси об'єкта вивчення, може бути створена на основі глибокого розуміння функцій і властивостей, які моделюються, а також виступає як аналогія і $€$ проміжною ланкою між висунутими теоретичними положеннями та їх перевіркою у реальному педагогічному процесі [3, с. 156].

Широке застосування методу моделювання у педагогічних дослідженнях дає змогу створювати оптимальні структури професійної підготовки фрахівців. У межах нашого дослідження створення моделі професійної підготовки майбутніх соціальних педагогів до фрормування життєвої компетентності підлітків у закладах загальної середньої освіти має на меті цільову, спеціальну й вузько спрямовану фахову підготовку майбутніх фрахівців соціальної сфрери, а також забезпечення процесу такої фрахової підготовки технологічною схемою, зразком, алгоритмом здійснення педагогічного впливу щодо набуття студентами профресійної компетентності з формування життєвої компетентності підлітків.

Розроблена модель (рис. 1) профресійної підготовки майбутніх соціальних педагогів до фрормування життєвої компетентності підлітків у закладах загальної середньої освіти має таку структуру: цільовий, концептуально-методологічний, змістовно-процесуальний та результативний блоки.

Охарактеризуємо складники розробленої моделі.

Цільовий блок становлять мета і завдання профресійної підготовки майбутніх соціальних педагогів до фрормування життєвої компетентності підлітків у закладах загальної середньої освіти. Профресійну підготовку майбутніх соціальних педагогів до фрормування життєвої компетентності підлітків у закладах загальної середньої освіти як мету конкретизують такі завдання: формування стійких мотивів у майбутніх соціальних педагогів зі сприяння молодому поколінню на шляху фрормування їхньої життєвої компетентності, соціалізації, 


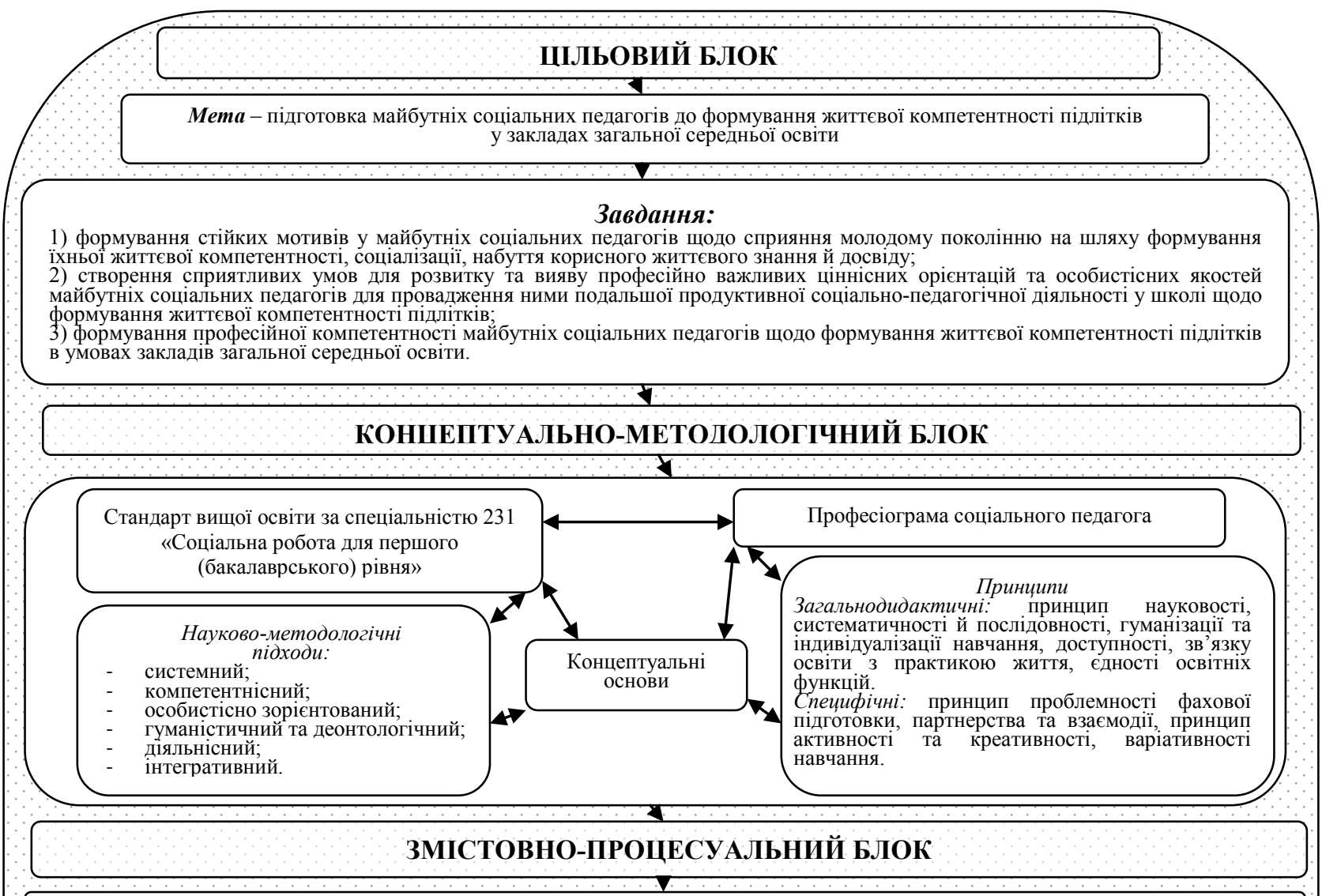

Компоненти: мотиваційно-ціннісний, особистісний, когнітивний, діяльнісний.

Етапи реалізації організаційно-педагогічних умов:

мотиваційний, інформаційно-діяльнісний, рефлексивно-корекційний.

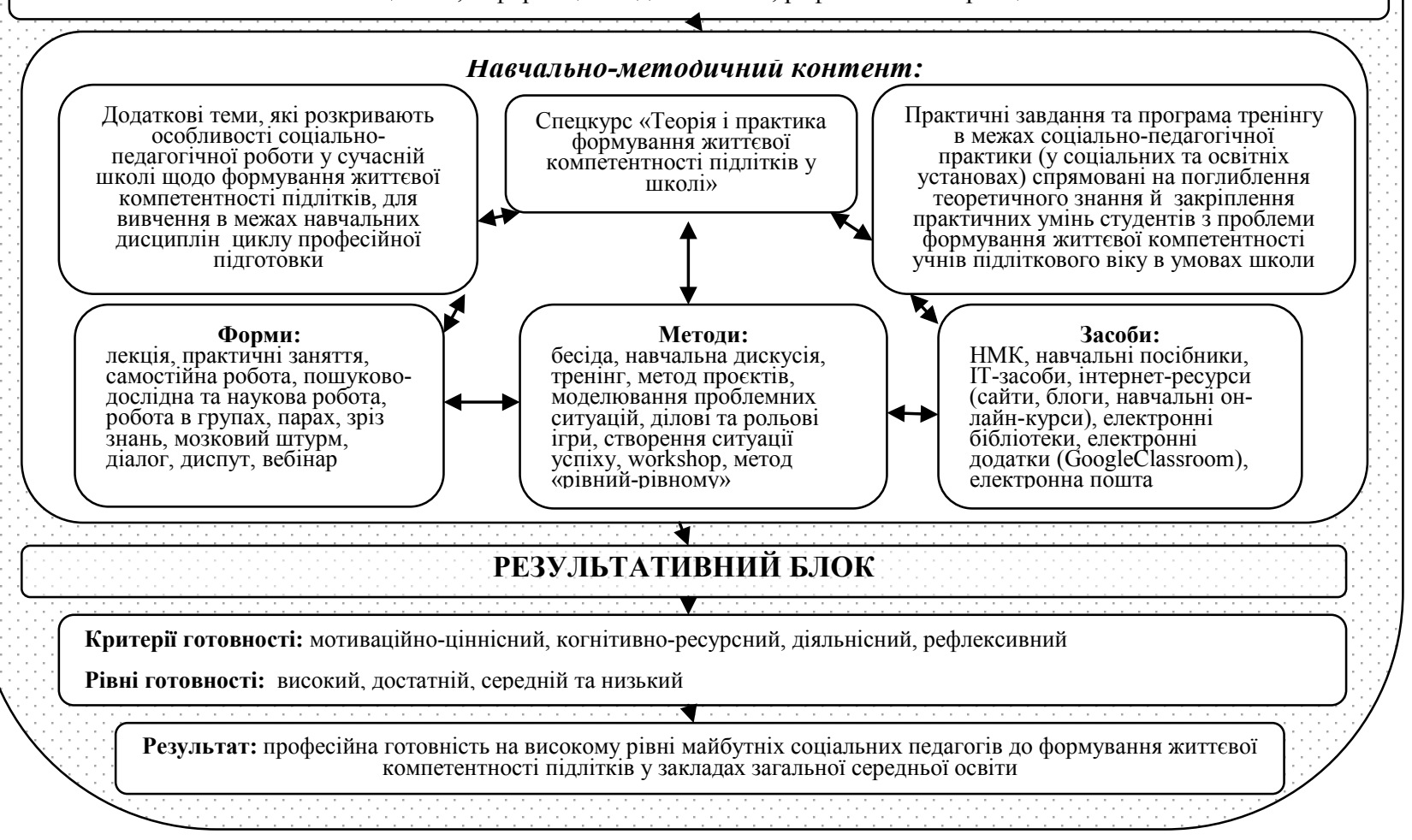

Рис. 1. Модель професійної підготовки майбутніх соціальних педагогів до фрормування життєвої компетентності підлітків у школі 
набуття корисного життєвого знання й досвіду; створення сприятливих умов для розвитку та вияву професійно важливих ціннісних орієнтацій та особистісних якостей майбутніх соціальних педагогів для здійснення подальшої продуктивної соціально-педагогічної діяльності з підлітками у школі щодо формування в них життєвої компетентності; формування професійної компетентності майбутніх соціальних педагогів, що включає відповідні знання, уміння і здатності, щодо фрормування життєвої компетентності підлітків в умовах закладів загальної середньої освіти.

Концептуально-методологічний блок містить посилання на стандарт вищої освіти за спеціальністю 231 «Соціальна робота для першого (бакалаврського) рівня» (Наказ Міністерства освіти і науки України від 24.04.2019 № 557) 3 окресленим ним переліком фрахових компетентностей, на професіограму соціального педагога, на концептуальні засади фахової підготовки майбутніх соціальних педагогів до фрормування життєвої компетентності підлітків у закладах загальної середньої освіти (педагогіка життєтворчості, педагогіка партнерства, інноваційні технології та методи навчання, компетентнісний та особистісно орієнтований підходи). Також цей блок містить наукові підходи та принципи, на яких ґрунтується професійна підготовка майбутніх соціальних педагогів у процесі здобуття освіти у ЗВО до роботи 3 підлітками у школі в напрямі фрормування їхньої життєвої компетентності.

Теоретичною та методологічною основою для створення моделі підготовки майбутніх соціальних педагогів до формування життєвої компетентності підлітків у закладах загальної середньої освіти стали системний, компетентнісний, особистісно зорієнтований, гуманістичний, деонтологічний, діяльнісний, діалогічний, інтегративний підходи.

Системний підхід є методологічною основою більшості сучасних педагогічних досліджень. Його основою $€$ фрілософрське вчення про цілісність системотворчих зв'язків і відношень, спрямованих на розвиток особистості [7, с. 47]. Системний підхід передбачає розкриття цілісності педагогічних об'єктів, виявлення в них різноманітних типів зв'язків і єднання їх в єдину теоретичну систему. Системний підхід покликаний сприяти безперервному вдосконаленню освітнього процесу через об'єднання й систематизацію наявного науковопрактичного досвіду. У підготовці майбутніх соціальних педагогів до формування життєвої компетентності підлітків у закладах загальної середньої освіти системний підхід реалізується через встановлення взаємозв'язків та взаємодії всіх компонентів профресійної підготовки майбутніх фрахівців у зазначеному напрямі.

Компетентнісний підхід передбачає спрямованість освітнього процесу на оволодіння здобу- вачами освіти загальними й професійними компетентностями, на фрормування у майбутніх фрахівців здатностей продуктивно розв'язувати професійні задачі, на розвиток професійно значущих умінь, засвоєння механізмів та алгоритмів успішної роботи за фрахом. Компетентнісний підхід у підготовці майбутніх соціальних педагогів до роботи з підлітками у школі в напрямі фрормування їхньої життєвої компетентності базується на фрормуванні у студентів здатності організовувати таку діяльність, провадити її з відповідною результативністю, налаштовувати доброзичливі стосунки та продуктивну взаємодію з усіма учасниками освітнього процесу задля комфрортного й успішного розвитку життєвої компетентності молодого покоління.

Особистісно зорієнтований підхід полягає у врахуванні індивідуальних характеристик студентів, їхніх особистісних якостей, нахилів і здібностей у процесі здобуття освіти. Особистісно орієнтований підхід передбачає повагу до індивідуальності особистості, її всебічний розвиток на засадах гуманізму та фрормування в неї цінностей самоповаги, гідності, особистісної унікальності й неповторності, самоцінності. Підготовка майбутніх соціальних педагогів до роботи з підлітками на основі особистісно орієнтованого підходу в змозі забезпечити позитивний приклад організації педагогічної діяльності з учнями, який продемонструє важливість і результативність суб'єкт-суб'єктних відносин, механізмів і засобів взаємодії на рівних, урахування індивідуальних особливостей особистості в процесі навчання і виховання.

Сучасним системоутворювальним чинником гуманістичної парадигми фрахової підготовки майбутніх працівників соціальної сорери виступають гуманістичний та деонтологічний підходи, які передбачають демократичний стиль взаємодії студентів і викладачів, взаємоповагу та орієнтир у процесі навчання на загальнолюдські цінності, індивідуальні здібності й задатки студентів, а також узгодження 3 нормами, принципами та цінностями діяльності майбутніх працівників соціальної сорери у профресійному просторі [5, с. 44].

Діяльнісний підхід в освіті передбачає орієнтацію освітнього процесу на обов'язкове застосування теоретичного знання у практичній діяльності, на розвиток необхідних компетентностей особистості для продуктивної діяльності в різних сорерах життя, на самоосвіту, успішну соціалізацію та професійну самореалізацію за допомогою включення особистості до різних видів діяльності. Діяльність виступає засобом розвитку особистості в різних напрямах, залучає до цього процесу все розмаїття форм, методів і прийомів освітнього процесу. Діяльнісний підхід дає змогу зробити підготовку майбутніх фрахівців соціальної сфери до роботи з підлітками в школі практико зорієнтованою, із засвоєнням алгоритмів професійної дії 
та накопиченням студентами соціально-педагогічного досвіду через участь у практикумах, воркшопах, залучення до волонтерської роботи, практичну підготовку в межах навчального плану тощо.

Інтегративний підхід передбачає побудову змісту освіти за допомогою дидактичної моделі, що розробляється на основі обґрунтованого поєднання елементів знань з різних предметів і реалізується 3 використанням інтегрованих фрорм і методів організації навчання [10]. У фраховій підготовці соціальних педагогів до формування життєвої компетентності підлітків інтегративний підхід дає змогу логічно об'єднати міждисциплінарні знання за цією проблемою, узгодити теоретичний і практичний складники такої підготовки, а також інтегрувати в освітній процес розмаїття сучасних та ефективних засобів, фрорм і методів навчання.

Організація професійної підготовки майбутніх соціальних педагогів щодо формування життєвої компетентності підлітків у школі передбачає не лише реалізацію вищевказаних методологічних підходів, а й орієнтацію на принципи (загальнодидактичні й специфрічні) організації освітнього процесу студентів у межах проблематики дослідження. Так, загальнодидактичними принципами виступають: принцип науковості, систематичності й послідовності, гуманізації та індивідуалізації навчання, доступності, зв'язку освіти з практикою життя, єдності освітніх функцій. До специфічних принципів належать: принцип проблемності фрахової підготовки, партнерства та взаємодії, принцип активності та креативності, варіативності навчання.

Змістовно-процесуальний блок моделі містить компоненти професійної готовності майбутніх соціальних педагогів до формування життєвої компетентності підлітків; організаційно-педагогічні умови профресійної підготовки майбутніх соціальних педагогів до роботи з підлітками у школі в напрямі формування у них життєвої компетентності та етапи їх реалізації; навчально-методичний контент (зміст, фрорми, методи і засоби) профресійної підготовки майбутніх соціальних педагогів до зазначеної діяльності.

Так, у ході дослідження компонентами професійної готовності майбутніх соціальних педагогів до фрормування життєвої компетентності підлітків у закладах загальної середньої освіти визначено: мотиваційно-ціннісний, особистісний, когнітивний, діяльнісний.

Сутність мотиваційно-ціннісного компонента полягає у формуванні стійкої мотивації студентів до організації профресійної соціально-педагогічної роботи, виявленні та реалізації потреби здійснення суспільно корисної діяльності, у фрормуванні загальнолюдських цінностей та особистісних цінностей щодо саморозвитку й самовдосконалення.
Особистісний компонент включає розвиток індивідуально-психологічних якостей особистості кожного студента паралельно із фрормуванням професійно-педагогічної спрямованості, професійно значущих якостей і здатностей; включає орієнтацію особистості на налагодження комунікацій, спілкування з оточуючими, зокрема 3 дітьми. Так, цей компонент передбачає, по-перше, фрормування адекватної самооцінки студентів, самокритичності, потреби в самоаналізі та рефлексії професійної діяльності, прагнення до особистісного й профресійного самовдосконалення; розвиток емоційної врівноваженості, налаштування на оптимізм; фрормування у майбутніх соціальних педагогів критичного мислення, креативності, послідовності у діях, наполегливості та цілеспрямованості; формування емпатійності, уважності, турботи та небайдужого ставлення до оточуючих, гуманності, доброти, справедливості, тактовності, працелюбності, організованості; по-друге, фрормування соціально та професійно важливих якостей та здібностей майбутніх соціальних педагогів (педагогічного такту, комунікативності, толерантності, готовності прийти на допомогу, відповідальності, здатності переконувати, поваги до дітей); по-третє, спонукання студентів до соціальної активності та волонтерської роботи (участь у соціальних проєктах, благодійних акціях, соціальних ініціативах; організація суспільно корисних заходів, превентивної соціально-педагогічної роботи).

Когнітивний компонент, своєю чергою, передбачає набуття студентами теоретичного знання (знання специоріки потреб та інтересів сучасних підлітків, особливостей роботи у різних мікросоціумах, фрункцій державних та недержавних установ у системі соціально-педагогічної діяльності, основ державної політики та соціально-правового захисту дітей та молоді, особливостей соціально-педагогічної діяльності у закладах загальної середньої освіти, знання соціології, педагогіки, психології та закономірностей розвитку особистості підлітка, принципів та методів соціальнопедагогічної роботи 3 дітьми, педагогіки життєтворчості) та практичних умінь (комунікативних, аналітичних, організаторських, прогностичних, проектувальних тощо).

В основі діяльнісного компонента покладено набуття студентами професійної та життєвої компетентності, серед яких - загальнонаукова, загальнокультурна, пошуково-дослідницька, методологічна, діагностична, проєктивна, організаційна, життєтворча, корекційно-реабілітаційна, здоров'язбережувальна, соціальна, інформаційна, самоосвітня, психологічна, комунікативна, тьюторська, рефлексивна, політико-правова, прогностична, інтегративна компетентності [9, с. 291-293].

Організаційно-педагогічними умовами професійної підготовки майбутніх соціальних педагогів 
до роботи з підлітками у школі в напрямі фрормування в них життєвої компетентності виступають:

1. Психолого-педагогічні: фрормування стійких мотиваційних установок майбутніх соціальних педагогів щодо розвитку життєвої компетентності підлітків у закладах загальної середньої освіти.

2. Організаційні: забезпечення комфортних умов для розвитку та вияву професійно важливих ціннісних орієнтацій, особистісних якостей майбутніх соціальних педагогів для ефективної організації соціально-педагогічної діяльності з підлітками у школі щодо фрормування в них життєвої компетентності.

3. Навчально-методичні: організація процесу оволодіння майбутніми соціальними педагогами професійними знаннями, уміннями й здатностями щодо фрормування життєвої компетентності підлітків в умовах закладів загальної середньої освіти за допомогою спеціального навчально-методичного контенту.

Етапами реалізації вищезазначених організаційно-педагогічних умов виділено: мотиваційний, інформаційно-діяльнісний, рефрлексивно-корекційний. Розглянемо визначені етапи детальніше.

Мотиваційний етап передбачає фрормування у студентів інтересу до обраної професії, стійких мотивів щодо опанування специфікою соціальнопедагогічної роботи в сучасній школі з підлітками в напрямі їх успішної соціалізації і фрормування життєвої компетентності, а також фрормування у майбутніх соціальних педагогів професійно значущих особистісних характеристик (особистісних якостей, ціннісних орієнтацій), ціннісного ставлення до реалізації соціально-педагогічних фрункцій, до особистісного й професійного зростання.

Інорормаційно-діяльнісний етап передбачає оволодіння студентами в процесі навчання профресійним знанням щодо провадження соціальнопедагогічної діяльності 3 підлітками в напрямі розвитку їхньої життєвої компетентності в умовах загальноосвітньої школи, а також активну практичну діяльність із набуття цінного профеесійного досвіду щодо реалізації компетентнісного підходу в освіті й налагодження продуктивної взаємодії 3 підлітками.

Рефрлексивно-корекційний етап передбачає самоаналіз студентів щодо власної професійної готовності до роботи з підлітками в школі щодо фрормування в них життєвої компетентності; вдосконалення соціально-педагогічного інструментарію та вироблення індивідуальної професійної траєкторії соціально-педагогічної роботи у зазначеному напрямі; визначення шляхів профресійного вдосконалення.

Ключову позицію у розробленій моделі професійної підготовки майбутніх соціальних педагогів до зазначеної діяльності займає специфічний, на наш погляд, навчально-методичний контент.
Поняття «контент» (від англ. content - вміст) це зміст, наповнення, сутність, об'єм чого-небудь залежно від контексту [1]. Контент є змістовим наповненням інформаційного носія (книги, фрільму, сайту, блогу, портфоліо, авторських розробок тощо). До терміна «контент» може бути включено все те, що містить інфрормацію (текстову чи візуальну), наприклад: текст, відео, аудіо, фротографії, інші зображення, інсрографріка. Характер контенту інфрормаційного носія може бути як статичним, так і динамічним, він може постійно оновлюватись.

У контексті нашого дослідження навчальнометодичне забезпечення процесу професійної підготовки майбутніх соціальних педагогів до фрормування життєвої компетентності підлітків є фрормою, що наповнена відповідним змістом (контентом).

Навчально-методичний контент розуміється нами як систематизований, інтегрований, логічно побудований і структурований, зрозумілий і доступний, а також якісний (перевірений, достовірний) матеріал навчального й методичного характеру, який розкриває здобувачам вищої освіти цілі, зміст основних ідей окремих тем (проблемних питань) навчальної дисципліни або практичної підготовки. Навчально-методичний контент, на наш погляд, $є$ квінтесенцією навчально-методичного комплексу, що адресований студентам. Він спрямовує підготовку майбутніх фрахівців на конкретний напрям професійної діяльності, глибоке вивчення окремих професійних питань та на відпрацювання студентами специфічних практичних умінь, розкриває методику фрахової підготовки. Важливою характеристикою навчально-методичного контенту $є$ його якість і доступність (у тому числі через мережу Інтернет, онлайн-ресурси) для всіх учасників освітнього процесу.

Так, навчально-методичний контент у контексті нашого дослідження включає зміст, фрорми, методи і засоби педагогічної взаємодії зі студентами в процесі набуття ними професійної освіти, зокрема в напрямі їх фрахової підготовки до роботи в закладах загальної середньої освіти щодо формування життєвої компетентності учнів підліткового віку.

Зміст зазначеного навчально-методичного контенту включає, по-перше, навчальні дисципліни циклу профресійної підготовки майбутніх соціальних педагогів: «Соціально-педагогічна робота в закладах освіти», «Технології соціально-педагогічної роботи», «Соціалізація особистості», структуру й сутність яких доповнено спеціальними темами, що мають розкрити студентам специфіку реалізації компетентнісного підходу в освіті та особливості соціально-педагогічної роботи у сучасній школі щодо формування життєвої компетентності учнів, зокрема підліткового віку.

По-друге, навчально-методичний контент містить спецкурс «Теорія і практика орормування жит- 
тєвої компетентності підлітків у школі», мета якого полягає у поглибленні знань і закріпленні умінь майбутніх соціальних педагогів у напрямі формування життєвої компетентності молодого покоління, а також який характеризується конкретною спрямованістю і вузькою спеціальною підготовкою фахівців до роботи з підлітками у загальноосвітній школі. Програму спецкурсу «Теорія і практика формування життєвої компетентності підлітків у школі» побудовано за модульним принципом i у своїй структурі вона передбачає вивчення студентами трьох змістовних модулів, кожен 3 яких спрямовано на оволодіння майбутніми соціальними педагогами такими професійними компетенціями, як: компетенції реалізації теоретичного знання у практичній роботі з учнями; компетенції креативного вирішення професійних задач та впровадження сучасних освітніх технологій у практику роботи соціального педагога в школі; компетенції щодо безперервного професійного зростання й самовдосконалення; компетенції налагодження комунікації з усіма учасниками освітнього процесу, продуктивної взаємодії з підлітками; компетенції критичного мислення; інфрормаційні компетенції; компетенції організації соціально-педагогічної діяльності на засадах освітнього менеджменту.

Методичний супровід освітнього процесу майбутніх фрахівців оптимізує їхню фрахову підготовку, адже забезпечує комплексність засвоєння ними професійних знань та умінь, конкретизацію та систематизацію отриманої в ході навчання інфрормації, а також забезпечує попередню ґрунтовну підготовку до навчальної роботи як студентів, так і викладача. Тому доцільною була розробка до спецкурсу методичних рекомендацій щодо проведення практичних занять та самостійної роботи студентів.

По-третє, навчально-методичний контент має у своїй структурі спеціально розроблені практичні завдання та програму тренінгу, які пропонуються до виконання майбутніми соціальними педагогами в межах проходження соціально-педагогічної практики (у соціальних та освітніх установах). Запропоновані практичні завдання для соціальнопедагогічної практики спрямовані на поглиблення й закріплення теоретичного соціально-педагогічного знання з проблеми фрормування життєвої компетентності учнів підліткового віку в умовах школи, а також на отримання студентами практичного педагогічного досвіду й відпрацювання практичних умінь щодо провадження професійної роботи з підлітками в школі щодо сприяння їх соціалізації, формуванню життєвих цінностей, саморозвитку й самореалізації, набуття ними важливих життєвих компетенцій задля успішної життєдіяльності.

Тренінг «7 цікавих зустрічей», який також виступає складником соціально-педагогічної практики, має на меті формування професійної компетентності майбутніх соціальних педагогів щодо організації соціально-педагогічної роботи у школі з підлітками в напрямі розвитку їхньої життєвої компетентності. Розроблений тренінг характеризується динамічністю й гнучкістю щодо вибору проблемних питань та форм педагогічної роботи у відповідності до цільової аудиторії, адже його особливістю є спрямованість на студентів - майбутніх соціальних педагогів з метою їх професійної підготовки до роботи з підлітками щодо формування у них важливих для успішної життєдіяльності компетентностей, на підлітків 3 метою формування у них життєвої компетентності, на практикуючих соціальних педагогів 3 метою підвищення їхньої професійної обізнаності в зазначеному напрямі соціально-педагогічної діяльності. Тренінг має дати змогу майбутнім фрахівцям соціальної сфери за допомогою цікавих форм і прийомів педагогічної роботи здобути інфрормацію про сутність життєвої компетентності особистості, про особливості іï фрормування, здобути досвід набуття життєвої компетентності через апробацію різних соціальних ролей, моделювання й практичне вирішення різних життєвих ситуацій, побудову життєвих планів та визначення шляхів їх досягнень, а також змогу навчитись вільно висловлювати власну думку, ділитись почуттями й враженнями, презентувати себе, результати своєї роботи і роботи групи, отримати досвід спілкування й можливість реалізації особистісних ресурсів та розкриття творчого потенціалу.

Ефективними формами, які покликані забезпечити реалізацію змісту навчально-методичного контенту щодо підготовки майбутніх соціальних педагогів до професійної діяльності у школі з підлітками в напрямі фрормування у них життєвої компетентності, на нашу думку, є як традиційні фрорми організації академічного навчання - лекція, семінар, практичне заняття, індивідуальна консультація, робота в групі (в парі, у мікрогрупі), самостійна робота, пошуково-дослідна та наукова робота, зріз знань, так і нестандартні, інноваційні форми організації навчання - інтегровані, тренінгові, інтерактивні заняття зі студентами, проєктна діяльність, інтернет-конференції, діалоги та диспути, вебінари, мозковий штурм, перегляд навчальних відео із подальшим обговоренням, розробка сценаріїв соціальної реклами та соціально-виховних заходів, інсценування життєвих ситуацій та проєктування їх вирішення, створення життєвих проєктів та портороліо, практикуми з опанування алгоритмів розв'язання життєвих задач і проблемних ситуацій. Методами реалізації змісту розробленого навчально-методичного контенту, які доцільно, на нашу думку, використовувати у професійній підготовці студентів у напрямі роботи 3 підлітками в школі щодо формування в них життєвої компетентності визначено: приклад, бесіду, розповідь, навчальну дискусію, ділові та рольові ігри, змагання, заохочення, моделювання та вирішення 
проблемних педагогічних ситуацій, створення ситуацій успіху, тренінг, медіацію, аналіз життєвих ситуацій, метод «рівний-рівному», метод проєктів, сторітеллінг, наставництво, peer-education, workshop, flash mob, педагогічні технології (технології життєвого проєктування, соціального партнерства, розвитку й стимулювання пізнавальної активності і творчих здібностей).

Забезпечення реалізації змістового складника навчально-методичного контенту здійснюється також за допомогою засобів навчання, якими виступають: друковані й електронні підручники, навчальні посібники, методичні рекомендації, словники, ІТ-засоби (комп'ютери, комунікотори, планшети з виходом до мережі Інтернет, мультимедійні та сенсорні дошки та ін.), інтернет-ресурси (сайти, блоги, інтернет-відео, навчальні онлайнкурси, репозитарії тощо), електронні бібліотеки, електронна пошта (e-mail) та зручний і затребуваний сьогодні GoogleClassroom.

Результативний блок розробленої моделі призначений для перевірки якісних і кількісних характеристик досягнення мети і завдань щодо професійної готовності майбутніх соціальних педагогів до роботи у загальноосвітній школі 3 підлітками в напрямі фрормування у них життєвої компетентності, для визначення ефективності й доцільності результатів такої підготовки в процесі здобуття вищої освіти. Цей блок містить критерії та рівні професійної готовності майбутніх соціальних педагогів до роботи з підлітками щодо фрормування у них життєвої компетентності в умовах закладу загальної середньої освіти, а також сформульовані очікування - результат роботи зі студентами.

Таким чином, запропонована модель включає логічно пов'язані елементи, розкриває їх сутність та фрунціональність, акцентує увагу на синхронності, паралельності й послідовності педагогічного впливу на процес фрахової підготовки майбутніх соціальних педагогів з орієнтиром на фрормування життєвої компетентності молодого покоління в умовах школи. Варто зазначити, що модель характеризується як цілісна і водночас як гнучка, динамічна й готова до модиорікацій та доповнень, адже її елементи можуть бути використані не лише комплексно, а й окремо або частково та у професійній підготовці майбутніх фрахівців соціальної сорери в інших напрямах роботи з учнями в школі.

Висновки. Отже, реалізація компетентнісного підходу до навчання й виховання, фрормування життєвої компетентності особистості учня стає актуальним завданням сучасної освіти, а разом з тим набуває великого значення й у контексті професійної підготовки майбутніх соціальних педагогів, які виступають помічниками й наставниками в процесі соціалізації та особистісного становлення молодого покоління. Моделювання професійної підготовки майбутніх соціальних педагогів у напрямі фрормування життєвої компетентності підлітків у закладах загальної середньої освіти дало змогу чітко визначити її структуру та презентувати у моделі. Перспективами подальших наукових розвідок вважаємо експериментальну перевірку запропонованої моделі, яка нині $€$ теоретичною та виступає своєрідною дидактичною стратегією професійної підготовки майбутніх соціальних педагогів до роботи в школі в напрямі формування життєвої компетентності підлітків.

\section{БІБЛІОГРАФІЧНИЙ СПИСОК:}

1. Cambridge Dictionaries Online. URL: https://bitly.su/tMBixO.

2. Бартєнєва І.О. Педагогіка вищої школи : навчальний посібник / І.О. Бартєнєва, І.М. Богданова, І.В. Бужина та ін. Одеса : ПДПУ імені К.Д. Ушинського, 2002. 344 с.

3. Гончаренко С.У. Педагогічні дослідження: методологічні поради молодим науковцям. Вінниця : ДОВ «Вінниця», 2008. 278 с.

4. Життєва компетентність особистості : науково-методичний посібник / За ред. Л.В. Сохань, І.Г. Єрмакова, Г.М. Несен. Київ : Богдана, 2003. 520 с.

5. Зозуляк-Случик Р. Теоретико-методологічний аналіз процесу формування професійної етики майбутніх соціальних працівників у вищих навчальних закладах. Педагогічні науки: теорія, історія, інноваційні технології. 2017. № 9 (73). С. 42-51.

6. Зязюн І.А. Сучасні дидактичні моделі і логіка учіння. Сучасні інформаційні технології та інноваційні методики навчання у підготовці фрахівців: методологія, теорія, досвід, проблеми : збірник наукових праць / ред. кол.: І.А. Зязюн та ін. Київ; Вінниця : ТОВ фрірма «Планер», 2000. С. 4-7.

7. Коломієць А.М., Лазаренко Н.І. Сучасні методологічні підходи в організації вищої педагогічної освіти. Науковий вісник Південноукраїнського національного педагогічного університету імені К.Д. Ушинського. Педагогічні науки. Одеса, 2016. № 3 (110). C. 47-52.

8. Концептуальні засади реформування середньої школи «Нова українська школа». 2016. 40 с. URL: https://www.kmu.gov.ua/storage/app/media/reforms/ ukrainska-shkola-compressed.pdf.

9. Нечипоренко В.В. Системний розвиток навчально-реабілітаційного центру як відкритої інноваційної соціально-освітньої інституції : монографрія. Запоріжжя : Видавництво Хортицького національного навчально-реабілітаційного багатопрофільного центру, 2013. 512 с.

10. Опачко М.В. Інтегративний підхід до реалізації дидактичного менеджменту у підготовці магістрів-срізиків. Збірник наукових праць Кам'янецьПодільського національного університету ім. Івана Огієнка. Серія : Педагогічна. 2016. Вип. 22. С. 43-45.

11. Соціологічна енциклопедія / уклад. О. Яременко та ін. Київ : АКАДЕМВИДАВ, 2008. 455 с.

12. Термінологічно-тлумачний словник «Моделювання економіки». URL: https://bitly.su/OXZtLXXc.

13. Філософський енциклопедичний словник / уклад. В. Шинкарук та ін. Київ : Інститут фрілософрії ім. Г.С. Сковороди НАНУ, 2002. 742 с.

14. Штофрф В.А. Моделирование и фрилософиия. Ленинград : Наука, 1966. 302 с. 